\title{
The Connection between National Culture and Organizational Culture: A Literature Review
}

\author{
Hassan Elsan Mansaray, Hassan Elsan Mansaray Jnr ${ }^{2}$ \\ ${ }^{1}$ Lecturer in Department of Business Administration and Entrepreneurship Development, Institute \\ of Public Administration and Management (IPAM) University of Sierra Leone, Freetown, Sierra Leone \\ ${ }^{2}$ Lecturer in Department of Governance and Leadership, Institute of Public Administration and \\ Management (IPAM) University of Sierra Leone, Freetown, Sierra Leone \\ Email: hassanelsan@gmail.com
}

\begin{abstract}
:
Although there is a major challenge for international business to successfully adapt various cultures and their influence on the everyday operations of businesses. Such aptness needs to comprehend culture, cultural variety, opinions, stereotypes and values. Culture directs the way human beings act and conduct themselves in certain situations in life. It also explicates the way people from time to time treat others or talk about others. Consequently, culture in this circumstances is understood by a distinct set of people through its ideas, values, and traditions. These are the ideas, values, aspirations and traditions formed overtime by organisations that justified them to label it as 'organizational culture'. This study made an analysis on the dissimilarities between national culture and organizational culture and discovered that Management under no circumstances can change a national culture, it can only know and utilize it. Whereas management can construct and occasionally change an organizational culture. Therefore, national culture dissimilarities exist more in values than in practices whilst organizational culture dissimilarities exist more in practices than in values.

Keywords:

culture; national culture; organizational culture
\end{abstract}

\section{Introduction}

Culture patterns the way human beings conduct themselves and their actions in some situations in life. Szydlo (2017) therefore, resolved that culture explains the manner in which people speak out about others. It also offers the basis for people to be conscious as human. As Szydlo put it 'it is always somebody's culture' since, it is produced by certain group of people who express themselves in it. Contiu (2011) mentioned the existence of various levels of cultures, which stretch from nationwide culture to familiarize corporate or organizational cultures. Within the organization, culture does similar function as character does to the individual which Conti termed as, 'a hidden yet unifying theme that provides meaning, direction and mobilization'. Thus, the significance of learning organizational culture is to determine the level at which an organization can maximize its performance (Contiu (2011).

According to Nicolescu \& Verboncu, (2008) culture is a group outcome since people that exist as well as work together in the similar social environment where they were taught how to conduct themselves completely or partially. Therefore, culture in this circumstances is understood by way of all its ideas, values, and traditions of a discrete set of people. Consequently, Nicolescu \& Verboncu consider organizational culture as a collection of values, beliefs, aspirations, expectations and behaviours formed over a period in various organizations that triumphs inside them and regulate the tasks and performance of those organisations either directly and indirectly in the long run. In consequence, understanding culture can prepare anyone for the tests of contemporary business setting. Cameron \& Quinn (2011) have 
also pointed out that variations in culture correspondingly have great impact on individual as well as groups of people in corporate organizations. In view of that, organisational culture have emotional impact on organizations in diverse levels. And it has been acknowledged to be one of the most powerful issues when considering organizational performance.

Because of globalization, companies these days are confronted with compounded trials. As a consequence, companies are required to make available varied workforce, that have their place in diverse cultural and ethnic groups, that can work together to attain the companies' common goals. In so doing, companies should at all times treat each individual fairly, irrespective of his/her cultural background and identity. In such situation, organizations must recognize the value of culture and handle the concerns of cultural differences in a preemptive way in order to achieve the needed results. All the same, those organizations that engage people that are not from the same cultures should react swiftly and innovatively to worldwide society trials. In addition, cultural differences cannot be deserted or disregarded. If overlooked or not mindful to them, it may possibly cost the organization dearly (Nikčević 2014).

Schein (1984) and Schein (2009) likewise defined culture as an established values and beliefs used by followers of a group that control the method people reason and perform inside the group setting. Culture is as well a normal simple communal traditions, which have been cultured by a cluster as they resolved their outside version problem and inside assimilation. This design has operated more adequate to be considered lawful and thus passed on to novel members as the right way to recognize, reason and sense relative to those complications.

Furthermore, Hofstede (1991a), Hofstede, (2001) defined Culture as a collective encoding of the mind that differentiates the members of one group or type of people from others. It is all the time a collective issue, however it can be linked to diverse closed societies. Inside each group there is a different kinds of individuals. As, physical appearance of individuals are made-up as wavering according to some bell curve; the disparity between cultures is considered as the shift of the bell curve - that is, when one moves from one society to the other. Mostly the word 'culture' is used for tribes or ethnic groups in anthropology; for nations in political science, sociology and management and; for organizations in sociology and management. A comparatively unknown field is the culture of occupations such as, engineers versus accountants, or academics of not the same disciplines. The word culture can likewise be employed to the genders, to generations, or to social classes. Nonetheless, altering the level of form studied can also change the nature of the perception of 'culture'. Societal, national and gender cultures, which children learn from their initial youth straight on, are much profoundly entrenched in the human mind than occupational cultures learnt at school than organizational cultures learnt on the job. The last are the same when people take a new job. Societal cultures subsist often undetectably in standards, in the sense of extensive inclinations to have a favourite in convinced circumstances over others. Organizational cultures happen in relative (visible and conscious) practices: the way people perceive what goes on in their organizational environment (Hofstede 2011).

Jones (2007) in his thoughts observed that the key term in Hofstede's definitions is the word 'programming'. In his belief, Jones experiences that culture is not something that is easily acquired but, a slow process of growing into a society that takes account of:

- learning values (dominant beliefs and attitudes),

- partaking of rituals (collective activities),

- modelling against heroes (role models), and

- understanding symbols (myths, legends, dress, jargon, lingo...) 
These ingredients of culture as pointed out by Jones (2007) are acquired from birth. They are influenced by family, school, religion, workplace, friends, television, newspapers and books, and many other sources.

\section{Review of Literature}

\subsection{National Culture and its Dimensions}

The term national culture deliberates on the shared values, comprehension, beliefs, norms, and main concerns that are mutual among members of a nation (Crane, et al. 2008). According to Scherer et al. (2006) national culture also talked about the learnt understanding that people utilize to construe knowledge as well as to produce social behaviour.

Kroeber \& Parsons (1958) observed that national culture has numerous meanings. Based on Kroeber \& Parsons (1958) perception, culture is one of the most leading and multidisciplinary subject. Kroeber \& Parsons stated that culture symbolizes conveyed and generated arrays of values, ideas, and other 'symbolic-meaningful systems' that serve as elements in the modelling of human behaviour and the objects created through behaviour. However, without doubt, the most extensively cited definition of national culture is from the Dutch researcher: Geert Hofstede, who supported immensely to the improvement of the learning of cultural impacts on organizations. Hofstede propounded that national culture symbolizes mental encoding that result to various forms of thinking, feeling and possible performance that were learnt during one's lifetime (Hofstede, 2001).

According to Matijević et al (n.d), there is a major challenge for international business to successfully adapt various cultures and their influence on the everyday operations of businesses. Such aptness needs to comprehend culture, cultural variety, opinions, stereotypes and values. Cornelius (1999); Moldoveanu and Ioan-Franc (2011) commented that in a global perspective, the term culture has at best two causes:

- organisational culture, linked to traditions, beliefs, rules of behaviour, as well as the managerial style of a company and;

- national culture connected to language, codes of conduct, attitude about human rights, ethical standards, and past influences depicting the individuals' behaviour in a region or a country.

In addition, Hofstede, (2011) stated that a Bulgarian scholar Michael Minkov in the 2000s, conducted a research where he used data from the World Values Survey (Minkov, 2007) which facilitated an additional calculation of the fifth, and the accumulation of a sixth dimensions of national culture (Hofstede 2010, Minkov, 2011). Dušan (2004), Connerley (2004), Korsakiené \& Gurina (2012), Ioan-franc et al (2013), Yildiz, (2014) and Mahbub, (2017) also mentioned in their articles the six dimensions of the national culture according to the Geert Hofstede theory. 'Dimensionalizing Cultures: The Hofstede Model in Context'. The following are the six dimensions of the national culture:

1. Power Distance, connected to the diverse solutions to the elementary problem of human disparity;

2. Uncertainty Avoidance, connected to the level of stress in a society in the face of an unidentified future;

3. Individualism versus Collectivism, connected to the incorporation of individuals into primary groups;

4. Masculinity versus Femininity, connected to the separation of expressive roles between women and men; 
5. Long Term versus Short Term Orientation, connected to the choice of concentration for people's hard work: the future or the present and past.

6. Indulgence versus Restraint, connected to the satisfaction versus regulation of simple human needs linked to relishing life.

Hofstede further commented that respective country has been placed comparative to other countries on a notch for each dimension. The measurements are statistically different and do happen in all potential groupings, even though some combinations are more recurrent than others. When the early endorsement was done as regards to the country differences in IBM's data from management trainees elsewhere; the Hofstede dimensions and the country scores were validated through replications by others, using the same or related questions with other cross-national populations (Hofstede 2010). Likewise, Daniels (2011) also observed that culture offers a guide or the information to how we think and behave.

\subsection{The Theory of Organisational Culture}

The model of organizational culture has its main background from the 'culture model' (Dauber et al 2012). As a result, Hofstede (1997), Nicolescu, and Verboncu, (2008) described organization culture as a set of values, beliefs, aspirations, attitudes, expectations, understandings, norms shared by members of organization. Also, behaviours that are shaped over time in different organizations that win through within these organisations that directly and indirectly regulates their roles and performances. Thus, it is accepted from one generation of employees to the next generation, and this is dogged by the norms for suitable behaviour inside the organization (Covin and Slevin, 1991). As a result, organizational culture serves as an essential source of continued competitive advantage because, it owns the features of a strategic asset i.e.: shortage, individuality, value making and non-trade aptitude (Barney, 1986; Hayton, 2005). For that reason, organizational culture transporters are men. Accordingly, the organization with an organizational culture practices can already made it a mental reality to the people and can become a characteristic of the company, which can have a strong impact on team members, thereby directing their behaviour according to the norms and values that set up its basis (Valentina \& Ileana 2017).

In addition, Deal and Kennedy (1982) maintained that organizational culture is made of values, nevertheless they are as well included in their description of the business environment, heroes, rites and rituals and, cultural links. According to O'Donnell \& Boyle (2008) observation on organizational culture is that it is a widely used term but then it is one that seems to give rise to a degree of doubt. They further observed that culture offers organisations the common sense of identity and determinations, 'through the organisations legends, rituals, beliefs, meanings, values, norms and language'. Moreover, it can also prescribe the manner in which things should be done around the organizations. Besides, an organisation's culture can sum up its successes through it high performances in the previous times, as a way of pointing to new comers what it is good at as well as what has functioned in the past. These practices can often be acknowledged without query by old members of an organisation.

O'Donnell \& Boyle (2008) however, explain the individualism of organizational cultures design and practice in a number of organizations. They emphasized that culture differs in organisations therefore, there is no one organizational culture. This notion is far and widely acknowledged in academic literature that distinct organisations have unique cultures. The academic literature in addition recognize that there may possibly be more than one culture within organisations. 
Furthermore, Schein (1992) describes organizational culture as the shape of simple beliefs that a specified group has created, learnt otherwise invented in learning to deal with its complications of outside familiarization and essential assimilation. Therefore, it is necessary to comprehend organizational lifecycle because, it is generally accepted that organizational cultures have influence on organisation's performance (Sokro, 2012). On the other hand, some critics, for example Alvesson (2002) has contended that the level at which organizational cultures have a direct link on performance is rather equivocal. As organizational culture generates vigor and impetus. For that reason, the vigor would cause the organization to transfuse and construct a new drive for achievement.

Nevertheless, Boddy (2002), maintained that organizational culture has a vital and straight effect on the behaviour of the people of an organization. He is convinced that organizational culture can also inspired an employee to perform to expectation because of the set organizational goals or it can depress or undermine employee's confidence which can hold back the performance of the organization. In continuance to this disagreement, it seems that management of most organizations appear to determine performance of their team or employees to some exclusive cultural practices in their organization. Whereas, others consider individual targets as the main motivating force to improve performance. So, appreciating organizational life is essential because it has been recognized far and wide that organizational cultures have an influence on organizational performance. As a result, the importance of organizational culture maintenances the suggestion that, in contemporary competitive and globalized corporate environment, there is enormous necessity for organizational development strategy at several workforce unit, as this can develop the organisation's culture (Sokro, 2012).

Mead and Andrews (2009) have observed that, the understanding of 'organizational culture' is difficult as the word did not have any single conventional meaning. Many different definitions have existed over time which may consist of organizational structure and rules, values, feelings, norms as well as the organizational climate. In a lot of cultures outside North America and Europe, the concept is bizarre to managements that can principally concerned with nurturing 'a sense of loyalty among the workforce'.

\subsection{Characteristics and Roles of Organizational Culture}

Valentina \& Ileana (2017) perceived that Human resource management practitioners in organizations need to have an understanding on how the environmental influences on both the internal and external environment of organizations. From a cultural viewpoint, the internal environment is the organizational culture, whereas the external environment is the branch of the culture as well as the socio-cultural. Valentina \& Ileana went further to mention the characteristics of organizational culture as follows:

- Culture is a true lifestyle for its members, who think through its influence as often taken for granted.

- Since culture encompasses assumptions, values and basic beliefs therefore; it has a tendency to be fairly constant over time. Moreover, once a culture is well recognized, it can persevere regardless of staff turnover, it can safeguard social continuity.

- The content of a culture may possibly comprise factors that are internal and external to the organization. Internally, culture can support innovation, risk-taking or secret information. Externally, culture can support the catch phrase 'customer above all' or immoral behaviour from competitors.

- Culture can have a colossal influence on organizational performance and satisfaction of its members. As a result, organizational culture is nothing more than trying to form their 
own cultural characteristics in order to be in competition with other companies; also to endure competition and develop positively.

\subsection{The Connection between National Culture and Organisational Culture}

According to Nikčević (2014) every organization possesses its own culture, that mainly subjective to the national culture of the society in which it was formed. Moreover, National culture regulates values of organizational culture of organisations/companies operating within its context, and therefore, has substantial power on organizational culture and, in addition to organizational behaviour. Furthermore, certain authors have argued that national culture impacts the style of philosophy of managers of diverse nationalities and cultures, which is predominantly apparent when these managers work together. Brooks made an instance that some cultures promote the right to freedom of expression, whereas other cultures think through that such right must be secondary in order to serve the interests of the society all together (Brooks, (2006).

Moreover, Dušan had mentioned that Geert Hofstede's concept of national culture had made an excessive step forward in acknowledging the relationship between organizational behaviour and cultural issues (Dušan 2004). In addition, Hofstede (1994) also suggests that people may sense national and organizational culture differences by using a set of dimensions. Dušan as well pointed out Hofstede's set of dimensions that examined the differences between national cultures through four dimensions which Hofstede labelled as set of dimensions such as: Power distance, Individualism, Masculinity vs. Femininity and Uncertainty Avoidance. Hofstede $(1980,2001)$, emphasized that Power Distance dimension is a fundamental dimension of national culture, which impacts leadership and subcultures in organizations.

Additionally, Hofstede (n.d) made an analysis on the dissimilarities between national culture and organizational culture. He stated that culture does not exist in a touchable sense, it is a creation of our thoughts and is only valuable as far as in the long run it can help us understand and foretell occurrences in the real world. National and organizational cultures are to a certain degree have varied phenomena such as: 'national cultures belong to anthropology, organizational cultures to sociology'. Therefore, 'Management can never change a national culture, it can only understand and use it. It can create and sometimes change an organizational culture'. The conception of culture does not relate to the level of individuals. Individuals have characters, only partially influenced by the culture in which they grew up. Furthermore, national cultures vary typically at the level of values, whereas organization cultures vary customarily at the level of the additional superficial practices, like: symbols, heroes, and rituals. Therefore, 'national culture differences are rooted in values learned before age 10; children learn them from parents who also acquired them before age ten, so they are quite stable and take generations to be changed'. On the contrary, organizational cultures are deep-rooted in practices learned on the job, and they can change much faster. Their ramifications on management are pretty different.

Besides, Trompenaars \& Hampden-Turner (1996) pointed out that there are two ways researchers normally observe when it comes to investigation on national culture. The first direction sees culture as something unspoken, which arises naturally. Another more shared view is that culture is something overt, which arise from social communication. On the other hand, Hofstede (1994) understands culture as a designed ways of thinking and feeling that set up the 'mental programming' differentiating members of one group from another. Such mental programming involves designs of ideas and particularly their fond of values, which are preserved and delivered from one generation to another. Values can be revealed in practices, 
together with rituals, heroes, and symbols. He further examined national and organizational cultures based on his understanding of culture. He contended that there are four expression of culture, and the variances between national and organizational culture were based on their diverse practices. Hofstede distinguishes between layers that have symbols that represent the most superficial culture often described as practice; strata that have values which represent the inmost demonstration of culture. And the intermediate layers that describe heroes and rituals which are indicative of the organizational culture. In his assumption, he asserts that national culture variances exist more in values and a lesser amount in practices; and organizational culture variances exist more in practices and a smaller amount in values.

Furthermore, according to Fleury \& Tereza (2009), the concept of culture was make known to management sciences in the late 60s. It was the method whereby European and American companies became multinationals, thereby increasing their operations to other continents. This venture, steered them to replicate their management practices so as to increase competitive advantages in countries other than their own countries through cheap labour, new markets or nearness to raw materials, among other reasons. However, even though they wanted to make a replica of their management practices as thoroughly as conceivable, the consequences were not often well-matched. Generally, managers were faced with problems they cannot handle in the multinational's home country. That was why the first thinking of culture that was used by management were related to those employed to describe national culture. Therefore, it was without doubt that the two types of culture were both exerting 'powerful influences' on employees. This kind of power influence was extraordinary to employees, particularly those of foreign companies, to be fronting fights between them. However, a company's culture may be informal whilst a country's culture could be somewhat formal. A company may be reassuring and recompensing risk-taking in a country where people generally opposed risk or, contra wise. Altogether, this call for some kind of doggedness to readjust the company and its employees' values and behaviours (Katz 2005).

Lastly, Acquaah, (2007), Crane, et al. (2008) \& Cantwell, et al. (2009), stated chronologically three important constituents of national culture. First, beliefs that can be expressed through large number of mental and verbal progressions that can reproduce knowledge and valuation of any episode. Second, tenets that are indicators that are utilized to display appropriate behaviour of individuals. These standards can be constant and enduring over time. Third, the customs, which are types of behaviours created habitually allowable or accepted way of conducting oneself in open situations. Also, the components of culture consist of language, religion, education, attitudes and manners. Scherer et al. (2006) underscored that these elements over and over again form the organizational culture inside an international organisation once operative in a foreign country. As stated by Rugman and $\mathrm{Li}$, (2007) that organization's approach to assimilate national culture, established rules in addition to governmental rules and regulations frequently affect the organizational culture of a multinational company. Moreover, the host country's rules and regulations concerning the handling of employees and the release of information can significantly affect the organizational culture of an organisation as well.

\section{Research Method}

The study appraised the connection between National culture and Organisational culture through the use of secondary data from interrelated journals, books as well as associated resources on websites to determine the link between National culture and Organisational culture. 


\section{Discussion}

Culture directs the way human beings act and conduct themselves in certain situations in life. It also explicates the way people from time to time treat others or talk about others. Consequently, culture in this circumstances is understood by a distinct set of people through its ideas, values, and traditions. These ideas, values, aspirations and traditions formed overtime by organisations that justified them to label it as 'organizational culture'. From experience, organisations have realize that enforcing organizational culture in their operations can determine the level at which an organization can take full advantage of its performance. Moreover, understanding culture can aid managers to be conscious of employees' cultural differences and at the same time improve their managerial skills in the long run. As, cultural diversity can occasionally influence several practices in the daily operations of a business. For this reason, it is necessary managers to manage 'cultural diversity' adequately so as to get the best results needed. Thus, any differences in culture can have a corresponding influence on individual as well as the collections of employees in any corporate organization. Hence, organizational culture have expressive impression on organizations in various stages. In addition it has been accepted as one of the dominant issue when considering organizational performance. Therefore, companies are necessitated to have diverse workforce (because of globalization), that can emanate from different cultural and ethnic backgrounds, that can be willing to work as a team, so as to achieve the companies' corporate goals. Thus, organisations/companies must at all times treat those individuals fairly, irrespective of their cultural background and identity. As resolved by Sokro, (2012) that 'in today's competitive and globalized corporate environment, there is huge need for organizational development strategy at various workforce departments, as this can improve the company's culture' though; management at times cannot alter the culture all by itself.

It has also been established that each organization has its specific culture that can be influenced by the national culture of any society where it operates. Furthermore, National culture controls the values of the organizational culture used by companies operating within its setting; and as a result, national culture has considerable power on organizational culture as well as organizational behaviour. That is why, some authors have contended that national culture impacts behaviours of managers from diverse nationalities and cultures, when they are working as a team. Moreover, the notion of national culture had made progress on appreciating the relationship between organizational behavior and cultural factors. Accordingly, management can no way transform a national culture, it can only comprehend it and subsequently use it. Management sometimes make or change an organizational culture but, not a national culture. As the understanding of culture does not limited to the level of individuals since, individuals have behaviours that are sometimes influenced by the culture in which they grew up.

Also, national cultures differ usually at the strata of values, while organizational cultures contrast habitually at the level of the supplementary artificial practices, like: symbols, heroes, and rituals. Consequently, national culture variances are deep-rooted in values acquired by children before the age 10 (ten). Moreover, children learn these values from their parents who subsequently learnt them before the age ten (10). Henceforward, these values are quite unchanging and may take generations to be transformed. Conversely, organizational cultures are inherent in practices acquired on the job over time and; can be changed depending on the changing market environment or in gaining 'competitive advantage'. Besides, this can be done much faster than changing a national culture. However, the implications on various managements can be pretty different. Therefore, national culture dissimilarities exist more in 
values than in practices whilst organizational culture dissimilarities exist more in practices than in values.

\section{Conclusion}

The study found out that there are divergences between national culture and organizational culture and learnt that management under no state of affairs can modify a national culture, it can only be familiar with and utilize it. While management can create and intermittently change an organizational culture. For this reason, national culture divergences subsist more in values than in practices, whilst organizational culture divergences subsist more in practices than in values.

\section{References}

Acquaah, M. (2007) Managerial social capital, strategic orientation, and organizational performance in an emerging economy, Strategic Management Journal, 28(12), 12351255. https://doi.org/10.1002/smj.632

Alvesson, M. (2002) Understanding Organizational Culture. UK: sage publication Limited.

Barney, J.B. (1986) Organizational culture: Can it be a source of sustained competitive advantage?, Academy of Management Review, 11(3): 656-665. https://www.jstor.org/stable/258317

Boddy, D (2002) Management. 2nd ed. Pearson education limited, Essex UK.

Brooks, I. (2006) Organizational Behavior: Individuals, Groups and Organization, (3rd ed.), New Jersey, Prentice-Hall.

Cameron K. S. and Quinn, R. E. (2011) Diagnosing and Changing Organizational culture, 3rd ed. San Francisco: Jossey-Bass.

Cantwell, J. Dunning, J. H. \& Lundan, S.M. (2009) An evolutionary approach to understanding international business activity: the co-evolution of MNEs and the institutional environment, Journal of International Business Studies, 41(4), 567-586. https://link.springer.com/content/pdf/10.1007\%2F978-1-137-54471-1_8.pdf

Connerley.qxd (2004) Cultural Frameworks and Their Importance for Leaders, SOURCE: Adapted with permission from Pedersen, P. (1997b). Culture-centered counseling interventions (pp. 25-26). Thousand Oaks, CA: Sage 03-Connerley.qxd 11/10/2004 12:59 PM. Retrieved from https://us.sagepub.com/sites/default/files/upmbinaries/4964_Connerley_I_Proof_2_Chapter_3.pdf on the 10/02/2019

Contiu L. C. (2011) The influence of culture on organizational structures in Romania, BDD A2828 c 2011. Universitatea Petru Maior Provided by Diacromia ro for IP 41.223.134 $57 \quad$ (2019- $02 \quad-03 \quad 11: 52 \quad 56 \quad$ UTC) Retrieved from http://www.diacronia.ro/indexing/details/A2828/pdf on the 10/02/2019

Cornelius, N. (1999) Human Resource Management: A Managerial Perspective. London: International Thompson Business Press.

Covin, J.G., Slevin D.P. (1991) A conceptual model of entrepreneurship as firm behavior, Entrepreneurship Theory and Practice, 16(1): 7-25

Crane, A., Matten, D. and Moon, J. (2008), "Corporations and Citizenship", Cambridge University Press, New York, NY.

Deal, T.E. and Kennedy, A.A. (1982) Corporate Cultures: The Rites and Rituals of Corporate Life. Addison Wesley Publishing Company

Daniels Fund Ethics (2011) - Debate: Organisational culture Vs National Culture. Daniels Fund Ethics Initiative University of New Mexico http://danielsethics.mgt.unm.edu

Dauber D., Fink G. and Yolles M. (2012) - A Configuration Model of Organizational Culture 
SAGE Open 1 -16 (C) The Author(s) 2012 DOI: 10.1177/2158244012441482 http://sgo.sagepub.com

Dušan M. (2004) The Influence of National Culture on Organizational Subcultures and Leadership Styles In Serbian Enterprises: An Empirical Analysis Original scientific paper UDK: 316.46(497.11) Primljeno: 11.06.2004 Retrieved from https://www.academia.edu/3835485/The_influence_of_national_culture_on_organiz ational_subcultures_and_leadership_styles_in_Serbian_enterprises_An_empirical_anal ysis on the $10 / 02 / 2019$

Fleury L. \& Tereza M. (2009) - Organizational Culture and the Renewal of Competences. Available online at http://www.anpad.org.br/bar BAR, Curitiba, v. 6, n. 1, art. 1, p. 1 14, Jan./Mar. 2009 Retrieved from http://www.scielo.br/pdf/bar/v6n1/v6n1a02.pdf on the $10 / 02 / 2019$

Hayton, J.C. (2005) Promoting corporate entrepreneurship through human resource management practices: A review of empirical research, Human Resource Management Review, 15: 21-41.

Hofstede G. (n.d) National Cultures, Organizational Cultures, and the Role of Management. Article from the book Values and Ethics for the 21st Century https://www.bbvaopenmind.com/.../national-cultures-organizational-cultures- andthe-role-of-management/

Hofstede G. (2011) The Hofstede Model in Context Hofstede, Dimensionalizing Cultures: The Hofstede Model in Context. Online Readings in Psychology and Culture, 2(1).https://doi.org/10.9707/2307-0919.1014

Retrieved from https://scholarworks.gvsu.edu/orpc/vol2/iss1/8/

Hofstede, G. (2010) The GLOBE debate: Back to relevance. Journal of International Business Studies, 41, 1339-46.

Hofstede, G. (2001) Culture's Consequences: Comparing Values, Behaviors, Institutions and Organizations across Nations. Thousand Oaks, CA: Sage

Hofstede, G. (1994). Uncommon sense about organisations: Case studies and field observations. Thousand Oaks, CA Sage.

Hofstede, G. (1991a) Culture and Organisations. New York, McGraw-Hill.

Hofstede, G. (1980) Culture's Consequences. Sage, Beverly Hills, CA

Loan-franc V., Kiri ${ }_{s}^{T}$, 'Costin C, širok K., dindire L. and Brâncoveanu' C. (2013) 'National Culture-Intellectual Capital Inter-Relationship in EU Countries Retrieved from https://www.ingentaconnect.com/content/doaj/0002?crawler=true

Jones M. L. (2007) Hofstede - Culturally questionable? This paper was originally published as Jones, M, Oxford Business \& Economics Conference ISBN: 978-0-9742114-7-3 June 24-26, 2007 Oxford University, UK Retrieved from http:/ / ro.uow.edu.au/cgi/viewcontent.cgi?article $=1389 \&$ context $=$ commpapers

Katz, L. (2005) Organizational versus National Culture, +1-469-522-3389 info@leadershipcrossroads.co www.leadershipcrossroads.com (C) Leadership CrossroadsTM, 2005 Retrieved from http://www.leadershipcrossroads.com/mat/Organizational $\% 20 \mathrm{vs} \% 20 \mathrm{National} \% 20 \mathrm{C}$ ulture.pdf

Korsakienė R. and Gurina O. (2012) Does national culture significantly impact organizational culture at SMEs journal of Security and Sustainability issues www.lka.lt/index.php/lt/217049/

Kroeber, A L., Parsons, T. (1958), The Concepts of Culture and of Social System. American Sociological Review, Vol.23, No.5, pp. 582-583 http://twren.sites.luc.edu/phil389\&elps423/kroeber_and_parsons.htm

Mahbub A. (2017) - The impact of national culture on the organizational culture: 
Multinational companies doing businesses in developing countries, Master Thesis Retrieved from portal.org/smash/get/diva2:1127462/FULLTEXT01.pdf

http://www.diva-

Matijević S., Raguž I. V. and Filipović D. (n.d) The Role of National Culture in Contemporary Business Environment JEL classification: M10, M16 Retrieved from https://hrcak.srce.hr/file/238200

Mead R. and Andrews T. G. (2009) - International Management Culture and Beyond, Fourth edition, A John Wiley and Sons, Ltd., Publication.

Minkov, M. (2011). Cultural differences in a globalizing world. Bingley, UK: Emerald Publishing

Moldoveanu, M., and Ioan-Franc. V. (2011) Management Benchmarks of Cultural Policy. Romanian Journal of Economics 2 (42): 75-89

Nicolescu O., Verboncu I., (2008) Fundamentals management organization, University Publishing, Bucharest.

Nikčević G. (2014) Faculty of Economics, University of Montenegro - The Influence of National Culture on Certain Types of Organizational Culture UDC 316.722: 005.32FACTA UNIVERSITATIS Series: Economics and Organization Vol. 11, No 2, pp. $\quad 149 \quad 162 \quad-\quad 162 \quad$ Retrieved from http://casopisi.junis.ni.ac.rs/index.php/FUEconOrg/article/view/560

O'Donnell O. and Boyle R. (2008) - Understanding and Managing Organisational Culture, CPMR Discussion Paper 40 Retrieved from https://www.ipa.ie/_fileUpload/Documents/CPMR_DP_40_Understanding_Managi ng_Org_Culture.pdf

Rugman, A. \& Li, J. (2007) Will China's multinational succeed globally or regionally?", European Management Journal, 333-43 https://pdfs.semanticscholar.org/3486/8e992c6d4bd08d7f6778252fc74e25d1169c.pd

Schein, E. H. (2009) Organizational Culture and Leadership. São Paulo: Ed. Atlas.

Schein, E. H. (1992) Organisational Culture and Leadership, Jossey Bass Publishers.

Scherer, A. G., Palazzo, G. \& Baumann, D. (2006) Global rules and private actors: toward a new role for the transnational corporation in global governance", Business Ethics Quarterly, 16(4), 505-532. https://www.jstor.org/stable/3857794

Sokro E. (2012) Analysis of the relationship that exists between organisational culture, motivation and performance. Problems of management in the 21st century Volume 3, $2012106 \quad$ Retrieved from http://www.scientiasocialis.lt/pmc/files/pdf/Sokro_Vol.3.pdf

Szydło J. (2017) The Influence of National Culture on Management Culture on the Example of Polish and Ukrainian Institutions, DOI: 10.19253/reme.2017.03.018 Quarterly Journal - $\quad$ No $\quad 3 / 2017 \quad$ (22) Retrieved from https://zie.pg.edu.pl/documents/30328766/61721453/REME_22_\%283-2017\%29Art18

Trompenaars, F. \& Hampden-Turner, C., (1996) Riding the Waves of Culture: Understanding Cultural Diversity. New York, McGraw Hill.

Valentina M. and Ileana P. O. (2017) -The Influence of Organizational Culture on Company Performance, "Ovidius" University Annals, Economic Sciences Series Volume XVII, Issue 2 / 2017 Retrieved from https://ideas.repec.org/a/ovi/oviste/vxviiy2017i2p435439.html

Yildiz M.L., (2014) The Effects of Organizational Culture on Corporate Entrepreneurship; International Journal of Business and Social Science Vol No. 5, 5(1); April2014 Retrieved from https://ijbssnet.com/journals/Vol_5_No_5_1_April_2014/4.pdf on the $10 / 02 / 2019$ 